\title{
MAIN INDICATORS OF THE OXIDANT-ANTIOXIDANT SYSTEM AND THEIR RELATIONSHIP WITH THE FORCE OF THE RESPIRATORY MUSCLES IN ADULT PATIENTS WITH COMMUNITY-ACQUIRED PNEUMONIA
}

\author{
*V.I. Bereznyakov \\ KHARKIV MEDICAL ACADEMY OF POSTGRADUATE EDUCATION, KHARKIV, UKRAINE
}

Background. Currently, pneumonia is the $4^{\text {th }}-5^{\text {th }}$ in the world in the structure of death causes after cardiovascular and cancer diseases, cerebrovascular pathology, injuries and poisonings.

Objective. The aim of the study was to evaluate the indicators of the oxidative-antioxidant system and their relationship with the strength of the respiratory muscles in adult patients with community-acquired pneumonia.

Methods. The study was carried out in the period 2017-2020 at the therapeutic department of the Municipal Non-Profit Enterprise "City Clinical Multidisciplinary Hospital No. 25" of Kharkiv City Council. The study involved 52 adult patients with community-acquired pneumonia (CAP) aged 18 to 80 years old. The control group consisted of 20 apparently healthy humans. The activity of malondialdehyde, catalase and superoxide dismutase, level of reduced glutathione, glutathione reductase and glutathione peroxidase were determined. The assessment of the RM strength was investigated by recording the maximum static pressures at the level of the mouth and nose with "closed" airways using a MicroRPM apparatus on the $1^{\text {st }}$ and $10^{\text {th }}$ days of illness.

Results. Dysfunction of expiratory respiratory muscles prevailed in patients with non-severe CAP, and inspiratory respiratory muscles - in the patients with severe CAP. Significant negative correlations of malondialdehyde with indicators of respiratory muscles strength and positive correlations with glutathione reductase, glutathione peroxidase, catalase, and superoxide dismutase were established.

Conclusions. The relations between prooxidant and antioxidant indicators and respiratory muscles strength complements the concept of the body systemic response on pulmonary inflammation - one of the markers of respiratory muscles dysfunction.

KEYWORDS: community-acquired pneumonia; respiratory muscles; oxidative-antioxidant system.

\section{Introduction}

Community-acquired pneumonia (CAP) is still one of the most urgent issues of contemporary medicine. CAP leads to a steadily high and growing morbidity. According to the WHO data in recent years, lower respiratory tract infections have become the third leading cause of death in the world, and over the past 30 years, the incidence rate has risen [1]. The mortality rate in hospitalized patients with a severe form of the disease varies from 14 to $40 \%$ and significantly increases among patients over 60 years old [2]. According to the literature, the number of disease forms with severe or protracted course is increasing with frequent complications of pneumonia such as abscess formation, acute respiratory failure, infectious toxic shock, etc. $[3,4,5]$. In each 3-4 patients

\footnotetext{
*Corresponding author: Vladyslav Bereznyakov, PhD, Associate Professor, Kharkiv Medical Academy of Postgraduate Education, Kharkiv, 61037 Ukraine.

Email: vladyslavbereznyakov@gmail.com
}

with CAP, the disease has a protracted course $[1,6,7]$.

That is why study continues for clarifying individual relations in the pathogenesis of CAP, improving programs for its diagnosis and therapy. One of the leading factors in the pathogenesis of CAP is the excessive production of reactive oxygen intermediates (ROI), which is associated with bacterial or viral-bacterial aggression and insufficiency of the compensatory potential of antioxidant defence (AOD). An imbalance in the oxidative-antioxidant system is one of the key factors in the development of oxidative stress (OS), which plays an important role in the implementation of the molecular-cellular mechanisms of the pathogenesis of respiratory diseases [8, 9]. Free radical processes are typical general biological protective reactions of the body, normally providing energy metabolism, proliferation, differentiation of cells, gene expression, immune and adaptive responses, etc. [10]. At the 
same time, excessive ROI initiates lipid peroxidation (LPO) with subsequent damage of cellular membranes, uncoupling oxidative phosphorylation, formation of energy insufficiency, disturbance of enzymatic activity of the detoxification systems $[11,12,13]$. Some studies have established that OS is the most important component of endogenous intoxication - an obligate manifestation of CAP, which has a significant effect on its clinical course. In the pathogenesis of CAP the glutathione redox system (enzymes form thioredoxin and glutaredoxin-dependent complexes) play a special role that maintain intracellular homeostasis, which resists the destructive effects of oxidative stress factors [12]. It has been proven that low glutathione intracellular concentration contributes to imbalance between prooxidants and antioxidants in the lungs, aggravation of inflammatory reactions and complications development.

Also, one of the most important issues in the pathogenesis of CAP, is dysfunction of the respiratory muscles (RM). Formation of RM dysfunction at CAP is characterized by the effect of local (alveolar inflammation) and systemic (endogenous intoxication) factors on muscle contraction $[2,12]$. It is assumed that these changes are caused by the destabilization of cell membranes, decrease in the rate of myopotential conduction and violation of the potassium and calcium intracellular transport, which provide muscle contraction [11, 13]. At the same time, there is no data in the scientific literature about influence of free radical processes on the functional status of RM in patients with CAP.

The aim of the study was to evaluate the indicators of the oxidative-antioxidant system and their relationship with the strength of the respiratory muscles in adult patients with community-acquired pneumonia.

\section{Methods}

The study involved 52 patients with CAP aged $20-60$ years (mean age $36.5 \pm 10.3$ ), who were treated in the therapeutic department of the Municipal non-profit enterprise "City Clinical Multidisciplinary Hospital No. 25" of Kharkiv City Council in 2017-2020. Diagnosis of CAP was based on the results of clinical, radiological, microbiological and laboratory studies. Non-severe CAP (NCAP) was diagnosed in 56 (72\%) patients, severe CAP (SCAP) - in 22 (28\%). Unilateral subsegmental inflammatory infiltration of the lung tissue was recorded in patients with NCAP, and SCAP was characterized by the presence in one or both lungs of multisegmental, lobar, or bilobar infiltrates. The etiological structure of CAP is mainly represented by Streptococcus pneumonia - 57.4\%, Haemophilus influenza - 23.4\%, Mycoplasma pneumonia - 13.4\%, Chlamydophila pneumonia - 5.8\%. The patients were treated according to the Recommendations of the International Society of Pulmonologists and the F.H. Yanovskyi National Institute of Phthisiology and Pulmonology (Kyiv, 2019). The average hospitalization period was $10.80 \pm 0.67$ days. All the patients signed informed consent.

The control group involved 45 apparently healthy humans $(\mathrm{AHH})$ of the same age (mean age 39.5 \pm 12.5 ).

The intensification of LPO processes was determined by the level of the final product malondialdehyde (MDA) in erythrocytes [14]. The total antioxidant activity (AOA) was assessed by the integral index in blood plasma. The intensity of the first line of AOD was investigated by the activity of the enzymes catalase and superoxide dismutase (SOD). Catalase activity was determined by the rate of utilization of hydrogen peroxide in the reaction mixture [15], and SOD in erythrocytes - by the ability to suppress the reduction of nitro blue tetrazolium. The state of the redox system was studied by the level of reduced glutathione (RG), the activity of glutathione reductase (GR), and glutathione peroxidase (GPO) in whole blood [16].

The assessment of the RM strength was carried out by recording the maximum static pressures at the level of the mouth and nose with "closed" airways using a MicroRPM apparatus (CareFusion, Great Britain) on the $1^{\text {st }}$ and $10^{\text {th }}$ days of illness. The maximum inspiratory pressure (MIP), maximum expiratory pressure (MEP) and sniff nasal inspiratory pressure (SNIP) were evaluated. MIP and SNIP characterized the strength of the inspiratory muscles, and MEP - the expiratory muscles. The correlation of SNIP with the level of transhiatal pressure can refer it to the indicators of the functional activity of the diaphragm. The maximum rate of expiratory and inspiratory pressures rises in the oral cavity (maximal rate of pressure development - MRPD exp and MRPD $_{\text {insp }}$ ) was assessed using the additional software PUMA (Micro Medical, UK). The RM strength was assessed in the sitting position after 3-fold execution of respiratory movements with the fixation of maximum result. The 
required values (RV) for MEP, MIP, SNIP were calculated using a previously developed model [17].

To analyse the statistical significance of differences between the groups, statistical processing of the research results was carried out depending on the distribution origin of the data as follows: if the distribution was close to normal, the analysis was performed using the methods of variation statistics, the Statistica 8.0 software package - the statistical two-way ANOVA method (Fisher LCD post-hoc test). If it was significantly different from normal, the differences between the groups were determined using the Kruskal-Wallis ANOVA and median test method. Correlation analysis was carried out in the same Statistica 8.0 package by means of parametric and nonparametric methods depending on the type of distribution. The statistical significance of the differences between the indicators of the control and experimental groups was determined by the Student's and Kruskal-Wallis's criteria using the Excel program. The level of $p<0.05$ was statistically significant [18].

\section{Results}

Group 1 involved 36 (69.2\%) patients with NCAP. Their metabolic profile was characterized by minimal violations of the oxidative-antioxidant balance. The patients of this group showed slight decrease of RG and moderate increase of redox system RG-GPO and GR enzymes at normal values of SOD and catalase (Table 1).

The analysed indicators showed adequate response to antioxidant protection, which ensured the neutralization of ROI and LPO products, which was confirmed by normal MDA values in erythrocytes.

Among these patients, the absolute values of the strength indices of expiratory RM were significantly lower in the group of AHH (MEP on $54.6 \%$ ), and the limitation of their inspiratory function was less evident (MIP - on 17\%, SNIP on $7 \%$ ) (Fig. 1, 2). In this case, the ratio of measured and RM was 78\% for MEP and $88 \%$ for MIP and SNIP, which indicated a predominantly expiratory variant of RM dysfunction.

Group 2 involved 16 (30.8\%) patients with SCAP, whose indicators were characterized by the most significant imbalance, as evidenced by significant increase of MDA level (by 29\%) against the background of decrease in $\mathrm{AOA}$ (by $18 \%$ ) and catalase (by 59\%).

The inhibition of the RG redox system was expressed by decrease in the concentration of RG in the blood (by 48\%) and decrease in GPO (in 1.7 times compare to the AHH). At the same time, compensatory increase in the content of GR (by $11 \%$ ) and SOD (by $45 \%$ ) did not ensure the restoration of oxidative-antioxidant homeostasis.

The study of the RM functional state in the patients of group 2 showed that with increase of the CAP severity and imbalance in the oxidative-antioxidant system, the degree of their strength signs deviation from the level of AHH significantly increased and reached the maximum level. In this case, the indicators of MEP and MRPD ${ }_{\text {exp }}$ in relation to the $\mathrm{AHH}$ group decreased in 2.0 times, SNIP - in 1.5, and MIP in 1.75 times, which indicated about development of pronounced expiratory-inspiratory type RM dysfunction. The obtained results confirmed that the power of inspiratory RM was more evidence limited in SCAP with a significant weakening of functional activity of the diaphragm.

The analysis of paired correlations showed that at the height of disease, there were multidirectional relations of varying intensity between the indicators of RM strength and

Table 1. Oxidative-antioxidant indicators of patients with CAP in various groups, ME (95\% CI)

\begin{tabular}{|l|c|c|c|}
\hline \multirow{2}{*}{ Indicators } & Apparently healthy & \multicolumn{2}{c|}{ Patients with CAP (n=52) } \\
\cline { 3 - 4 } & humans $(\mathrm{n}=45)$ & Group 1 & Group 2 \\
\hline $\mathrm{MDA}, \mu \mathrm{mol} / 1 \mathrm{gHb}$ & $7[6,9 ; 71,0]$ & $7,3[7,1 ; 7,6]$ & $9[8,9 ; 9,2]^{*}$ \\
\hline $\mathrm{AOA}, \%$ & $70,3[68 ; 72,0]$ & $68,6[66,2 ; 70,1]$ & $59,4[57,5 ; 61,8]^{*}$ \\
\hline $\mathrm{MDA} / \mathrm{AOA}, \mathrm{c.u}$. & $0,14[0,13 ; 0,16]$ & $0,13[0,11 ; 0,15]$ & $0,16[0,15 ; 0,17]^{*}$ \\
\hline $\mathrm{RG}, \mathrm{mol} / 1 \mathrm{gHb}$ & $6,7[6,4 ; 7,1]$ & $5,8[5,6 ; 6,0]$ & $4,5[4,2 ; 4,8]^{*}$ \\
\hline $\mathrm{GPO}, \mu \mathrm{mol} \mathrm{RG} / 1 \mathrm{gHb} / \mathrm{hour}$ & $128[127 ; 133]$ & $149[142 ; 155]^{*}$ & $74[71,5 ; 76]^{*}$ \\
\hline GR, $\mu \mathrm{mol} \mathrm{NADPH} / 1 \mathrm{gHb} / \mathrm{hour}$ & $154,3[153,5 ; 156]$ & $164[158 ; 169]^{*}$ & $171,3[160 ; 181]^{*}$ \\
\hline Catalase, \% & $80[75 ; 84]$ & $77[73 ; 81]$ & $51,2[48,6 ; 54]^{*}$ \\
\hline SOD, \% & $54[51 ; 58]$ & $57,3[56 ; 59]$ & $78,3[77 ; 80]^{*}$ \\
\hline
\end{tabular}

Notes: * $-p<0,05$ statistically significant difference compare to the apparently healthy humans. 


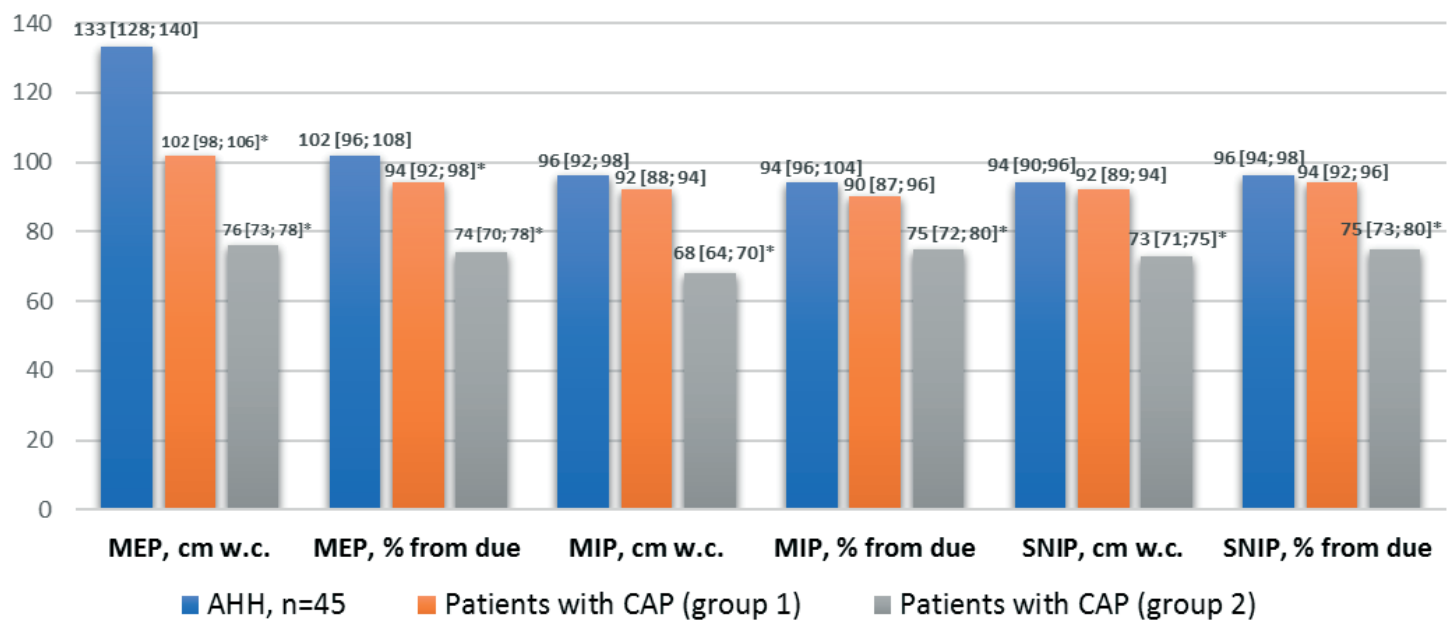

Fig. 1. Indicators of RM strength in patients with community-acquired pneumonia in various groups, ME 95\% CI) Notes: ${ }^{*}-p<0.05$ statistically significant difference compare to the apparently healthy humans.

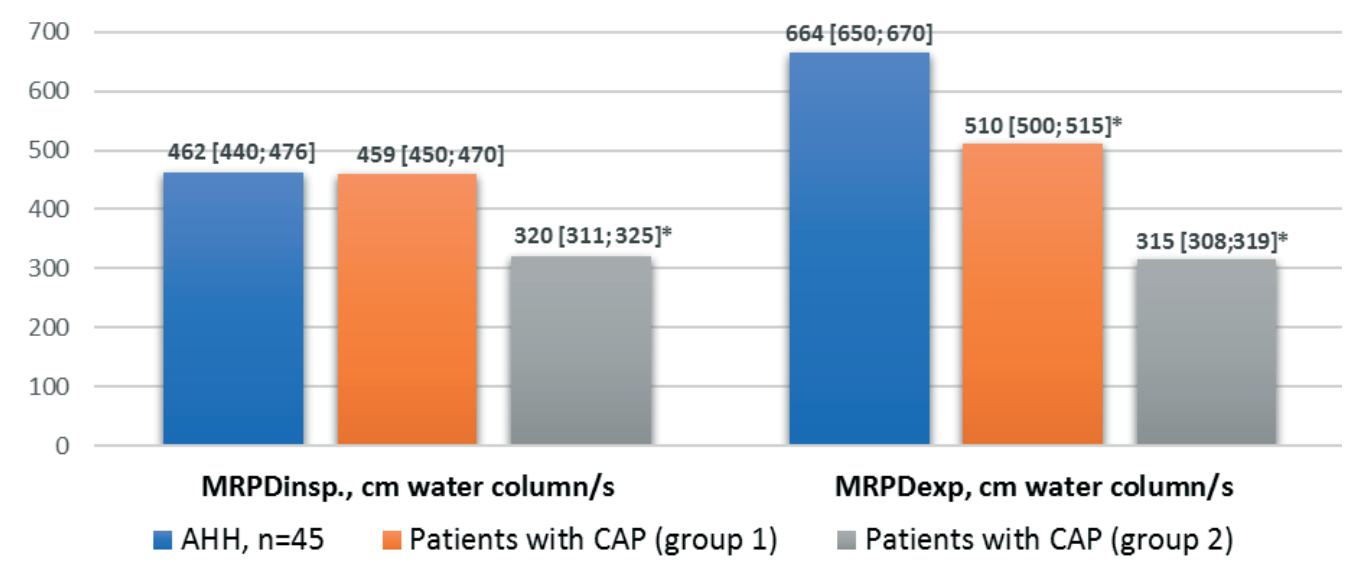

Fig. 2. Indicators of RM strength in patients with community-acquired pneumonia in various groups, ME (95\% CI) Notes: * $-p<0.05$ statistically significant difference compare to the apparently healthy humans.

some indicators of the oxidative-antioxidant status. Thus, negative correlations of the average strength of MDA with MEP $(r=-0.56)$, MDA with MRPD $_{\text {exp }}(r=-0.53)$, MDA with SNIP $(r=-0.61)$ and MDA with MIP $(r=-0.58)$ were evidenced. Direct correlations were found between the indicators MIP with GPO $(r=0.76)$, SNIP with catalase $(r=0.65)$, SOD with SNIP $(r=0.51)$, GR with MEP $(r=0.48)$. The obtained result indicates about the heterogeneity of the effect of prooxidant and antioxidant factors on the functional status of RM and confirm their role in the development of DM dysfunction.

On the $10^{\text {th }}$ day, the patients of the group 1 showed tendency to restoration of the strength indicators to the level of the AHH. At the same time, only MIP, SNIP, and MRPD ${ }_{\text {insp }}$ indicators reached the values of $\mathrm{AHH}$ group, while MEP and MRPD ${ }_{\text {exp }}$ significantly differed, which indicated persisting signs of isolated expiratory
RM dysfunction. In the patients of the group 2 on the $10^{\text {th }}$ day of studying, the medians of all indicators of the RM strength were minimal compare to other groups.

\section{Discussion}

Analysis of the scientific literature showed that the role of DM in the pathogenesis of CAP is not fully understood. It was noted, that decrease in the peak expiratory flow rate at the height of CAP is associated not with increase of bronchial resistance to expiratory air flow, but with DM dysfunction.

In the works of Geltser B.I. et al. (2019) the pathophysiological significance of endogenous intoxication in the development of DM dysfunction in alveolar inflammation has been proven [12]. Its development in this case is associated with the effect of systemic factors of acute inflammation on DM, including pro- 
ducts of oxidative stress, excessive proteolysis, bacterial toxins, pro-inflammatory cytokines and other inflammatory mediators that impair the efficiency of respiratory myofibrils. In previous study of Segizbaeva M. O, Aleksandrova N. P. (2014) it was found that in CAP, even endogenous intoxication could cause limitation of the contractile function of DM [13].

In resistive respiration, intensely contracting myocytes are able to transform into metabolic bridgehead producing spectrum of proinflammatory cytokines. At the same time, breathing resistance is considered as an "immune challenge" to the body with excessive synthesis of inflammatory mediators. It has been established that DM fatigue can also develop in healthy individuals with intense respiratory muscle stress $[12,13]$.

It is established, that the deficiency of glutathione enzymes contributes to damage of cell membranes and macromolecules - proteins, lipids, DNA and can determine the development of extrapulmonary manifestations of alveolar inflammation, including through damage to the myofibrils of skeletal muscles [7].

The obtained results can identify pathophysiological determinants that combine changes in the oxidative-antioxidant system and the RM functional activity in CAP. This is an imbalance in the LPO-AOD system, characterized by excess lipoperoxides and hypofunction of the first and second lines of AOD. Deficiency of the key intracellular antioxidant - glutathione, contributes to increase in OS, which becomes as key factor in the initiation of the molecular-cellular mechanisms of alveolar inflammation and RM dysfunction. Criteria for the severity of CAP in most cases corresponded to the severity of changes in the prooxidant and antioxidant system. At the same time, the heterogeneity of prooxidant processes among patients with NCAP, who were included in the group 1 , may be due to individual typological characteristics of the organism, including genetic [19]. The important role of individual components of LPO-AOD (MDA, GPO, GR, catalase, SOD) in the development of expiratory and inspiratory RM dysfunction was confirmed by the results of correlation analysis. The presence of interrelations between prooxidants and antioxidants and indicators of RM strength, complements the concept of the body systemic response on pulmonary inflammation - one of the markers of RM dysfunction.

\section{Conclusions}

An imbalance in patients with communityacquired pneumonia in the system of lipid peroxidation and antioxidant defence, which is characterized by overproduction of lipoperoxidases and hypofunction of antioxidant defence has been established. Increased oxidative stress in patients with community-acquired pneumonia causes deficiency of the key intracellular antioxidant - glutathione. Glutathione is key factor in the initiation of the molecular and cellular mechanisms of alveolar inflammation and respiratory muscles dysfunction in patients with community-acquired pneumonia. The relations between prooxidant and antioxidant indicators and the respiratory muscles strength complements the concept of the body systemic response on pulmonary inflammationone of the markers of respiratory muscles dysfunction. The obtained results will optimize the diagnosis of community-acquired pneumonia and its severity.

\section{Conflicts of Interest}

Authors declare no conflict of interest.

Authors' Contributions

Vladyslav Bereznyakov - investigation, conceptualization, formal analysis, writing original draft.

\section{ОСНОВНІ ПОКАЗНИКИ ОКСИДАНТНО-АНТИОКСИДАНТНОЇ СИСТЕМИ І ЇХ ВЗАЄМОЗВ'ЯЗОК З СИЛОЮ ДИХАЛЬНИХ М'ЯЗІВ У ДОРОСЛИХ ХВОРИХ, ЩО СТРАЖДАЮТЬ НА ПОЗАЛІКАРНЯНУ ПНЕВМОНІЮ}

B.I. Березняков ХАРКІВСЬКА МЕДИЧНА АКАДЕМІЯ ПІСЛЯДИПЛОМНОЇ ОСВІТИ, ХАРКІВ, УКРАЇНА

Вступ. В даний час пневмонії займають 4-5 місце в світі в структурі причин смерті після серцевосудинних і онкологічних захворювань, цереброваскулярної патології, травм і отруєнь.

Мета дослідження - оцінити показники оксидантно-антиоксидантної системи та їх взаємозв'язок з силою дихальних м'язів у дорослих хворих, що страждають на позалікарняну пневмонію. 
Методи дослідження. Дослідження проведено у період 2017-2020 рр. на базі терапевтичного відділення Комунального некомерційного підприємства "Міська клінічна багатопрофільна лікарня № 25" Харківської міської ради. У дослідженні брали участь 52 дорослих пацієнтів, що страждали на ПП, віком 18 до 80 років. Контрольну групу складали 20 практично здорових людей. Визначено активність малонового диальдегіду, каталази та супероксиддисмутази, рівень відновленого глутатіону, глутатіонредуктази та глутатіонпероксидази. Оцінку сили дихальних м'язів досліджували шляхом реєстрації максимальних статичних тисків на рівні порожнини рота та носа при "закритих" дихальних шляхах за допомогою апарату MicroRPM на 1-у та 10-у добу захворювання.

Результати. Дисфункція експіраторних дихальних м'язів переважала у пацієнтів з нетяжкою формою ПП, а інспіраторних дихальних м'язів - у пацієнтів з тяжкою формою ПП. Були встановлені негативні кореляції між рівнем малонового диальдегіду та показниками сили дихальної мускулатури, а також позитивні кореляції - з глутатіонредуктазою, глутатіонпероксидазою, каталазою та супероксиддисмутазою.

Висновки. Виявлені взаємозв'язки між про- і антиоксидантними показниками і силою дихальних м'язів доповнюють уявлення про системну реакції організму на легеневе запалення, одним з маркером якої є дисфункція дихальних м'язів.

КЛючОВІ СЛОВА: позалікарняна пневмонія; дихальні м'язи; оксидантно-антиоксидантна система.

Information about the authors

Vladyslav Bereznyakov, PhD, Associate Professor, Department of General Practice - Family Medicine, Kharkiv Medical Academy of Postgraduate Education, Kharkiv, Ukraine.

ORCID 0000-0001-7818-4864, e-mail: vladyslavbereznyakov@gmail.com

\section{References}

1. Avdeev SN, Chuchalin AG. [Severe communityacquired pneumonia]. Russian medical journal 2001; 5:177-181. (In Russian).

2. Lanks CW, Musani AI, Hsia DW. Communityacquired Pneumonia and Hospital-acquired Pneumonia. Med Clin North Am 2019; 103(3): 487-501.

DOI: $10.1016 /$ j.mcna.2018.12.008.

3. Prina E, Ranzani OT, Torres A. Communityacquired pneumonia. The Lancet 2015; 386(9998): 1097-1108.

DOI: $10.1016 / S 0140-6736(15) 60733-4$.

4. Wunderink RG, Waterer G. Advances in the causes and management of community acquired pneumonia in adults. BMJ 2017; 358: j2471.

DOI: $10.1136 / \mathrm{bmj} . j 2471$.

5. Eshwara VK, Mukhopadhyay C, Rello J. Community-acquired bacterial pneumonia in adults: An update. Indian J Med Res 2020; 151(4): 287-302.

DOI: 10.4103/ijmr.IJMR_1678_19.

6. Chuchalin AG, Sinopalnikov AI, Kozlov RS, Avdeev SN, Tyurin IE et al. [Diagnosis, treatment and prevention of severe community-acquired pneumonia in adults]. Pulmonology 2014; 4: 13-48. (In Russian).

7. Kolek V, Jakubec $P$, Losse S. Diagnostics and treatment of community-acquired pneumonia simplicity is the key to success. Vnitr Lek 2018; 63(11): 770-775.

8. Ozlek E, Biteker FS, Cil C, Celik O et al. The risk stratification in community-acquired pneumonia. The American Journal of Emergency Medicine 2019; 37(1): 171.

DOI: https://doi.org/10.1016/j.ajem.2018.05.061
9. Jones B, Waterer G. Advances in communityacquired pneumonia. Therapeutic Advances in Infectious Disease 2020; 7: 1-11.

DOI: $10.1177 / 2049936120969607$

10. Soodaeva SK, Klimanov IA, Nikitina LYu. [Nitrosative and oxidative stress in respiratory diseases]. Pulmonology 2017; 2(27): 262-273. (In Russian).

11. Demidchik LA, Muravleva LE, MolotovaLuchanskaya VB, Bakirova RE, Klyuev DA et al. [Characteristics of the oxidative metabolism of erythrocytes in patients with community-acquired pneumonia]. Bulletin of the East Siberian Scientific Center of the Siberian Branch of the Russian Academy of Medical Sciences 2016; 3-2(109): 26-28. (In Russian).

12. Geltser BI, Kurpatov IG, Dey AA, Kozhanov AG. [Respiratory muscle dysfunction and respiratory diseases]. Therapeutic archive 2019; 91(3): 93-100. (In Russian).

13. Segizbaeva MO, Aleksandrova NP. [Assessment of the resistance of different groups of inspiratory muscles to fatigue during exercise against the background of simulated airway obstruction]. Fiziol. person 2014; 40(6): 683-689. (In Russian).

14. Stalnaya ID. [Method for the determination of malonic dialdehyde using thiobarbituric acid. Modern methods in biochemistry]. Moscow: Medicine, 1977: 66-68. (In Russian).

15. Girin SV. [Modification of the method for determining the activity of catalase in biochemical substrates]. Lab. diagnostics 1999; 4: 45-46. (In Russian). 
16. Saydam N, Kirb A, Demir O, Hazan E, Oto O, Saydam O, Güner G. Determination of glutathione, glutathione reductase, glutathione peroxidase and glutathione S-transferase levels in human lung cancer tissues. Cancer Lett. 1997; 119(1): 13-9.

DOI: 10.1016/s0304-3835(97)00245-0.

17. Kabitz HJ, Walterspacher S, Mellies U. et al. Recommendations for respiratory muscle testing. Pneumologie 2014; 68(5): 307-314.

DOI: $10.1055 / \mathrm{s}-0034-1365283$
18. Lapach SN, Chubenko AV, Babich PN. [Statistical Methods in Biomedical Research Using Exel]. 2nd ed. K.: Morion, 2001; 408 p. (In Russian). 19. Somov DA, Makarova MR, Makarova IN. [The value of muscle imbalance for the development of therapeutic exercises in patients with pneumonia]. Questions of balneology, physiotherapy and physical therapy 2015; 3(92): 7-10. (In Russian).

Received 27 May 2021; revised 20 Jun 2021; accepted 21 Jun 2021.

This is open access article distributed under the Creative Commons Attribution License, which permits unrestricted use, distribution, and reproduction in any medium, provided the original work is properly cited. 